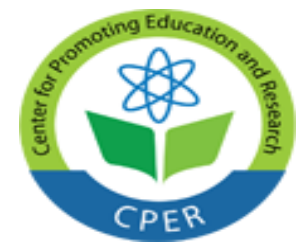

VOL: 1, ISSUE: 2

February/2019

https://ijssppnet.com/

E-ISSN: $x x x x-x x x x$

(C) Center for Promoting Education and Research (CPER) USA

WWW.cpernet.org

\title{
EFFECT OF EXCHANGE RATE AND INTEREST RATES SBI RUPIAHS TO GAIN SHARE PT. INDOFOOD SUKSES MAKMUR TBK
}

Wirya Hadinata $^{1}$, P. Eddy Sanusi ${ }^{2}$, Djoko Setyo Widodo ${ }^{3}$

Faculty of Economics

Universitas Krisnadwipayana

Indonesia

\section{ABSTRACT}

This study aimed to determine the effect of exchange rate and interest rate SBI to simultaneously benefit the company's shares, determine the effect of the exchange rate to gain partial shares of the company and determine the effect of SBI interest rate of the company's stock price partially.

The study was conducted at PT. Indofood CBP Sukses Makmur Tbk. The data used for 4 years were taken monthly or as many as 48 data. The data is sourced from the website of Bank Indonesia, Foam Indonesia, and the World Investment Securities.

Based on data analysis known that the variable exchange rates and interest rates SBI affect the company's stock gains simultaneously. Calculated $F$ value of 16.943 with a significance of 0.00 . The significance value of less than 0.05 is the value of alpha. $R$ squared value of $43.0 \%$. It means variable exchange rate and the SBI interest rate effect on profit shares of the company amounted to $43.0 \%$ while the rest influenced by other variables not included in the model equations. The exchange rate has no effect on the company's stock gains were studied. T value of 0.872 with a significance value of 0.388 . The significance values greater than 0.05. $R$ squared value of $1.6 \%$. This value shows the effect of the exchange rate variable to stock gains of $1,6 \%$ and the rest is influenced by other variables that are not included in the analysis tables. Variable SBI affects the profit shares of the company being investigated. T value of 4.498 with a significance value of 0.00. The significance value less than 0.05. $R$ squared value of 30.5\%. This value indicates the SBI variables influence on stock gains of $30.5 \%$ and the rest is influenced by other variables that are not included in the analysis tables.

\section{Keywords: exchange rate, interest rates SBI, stock gains}

Jel Classification: E31, E32

\section{Introduction}

Capital market performance indicators can be seen from the price development that occurs in the market. The stock price is formed through the mechanism of supply and demand in the capital market. If a stock is oversubscribed, then the stock price tends to rise. Conversely, when the excess supply of the stock price tends to fall (Sartono, 2008). The stock price can determine stock investment gains on the stock exchange. The advantage is the difference between the selling price and the purchase price of shares received by investors. If the purchase price of the stock is greater than the selling price of the shares will occur a stock or capital gains. If the purchase price of the stock is greater than the selling price will gain capital losses or lost.

Factors that influence the dividend is the exchange rate of foreign currencies, especially the dollar against the rupiah. Increase or decrease in the open price of the dollar will have an impact on investor interest to increase or decrease the investment in the dollar and the impact on the increase and decrease in stock prices. In conditions where the dollar strengthened against the rupiah indicated that investors will generally invest their money by buying the US 


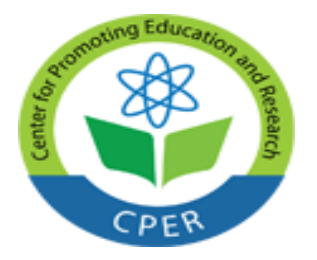

VOL: 1, ISSUE: 2

February/2019

https://ijssppnet.com/

E-ISSN: $x x x x-x x x x$

\section{(C) Center for Promoting Education and Research (CPER) USA}

WWW.cpernet.org

dollar by pulling their investments in stocks that stocks declining demand and impact on the stock price on the stock In January 2014 exchange rate of 1 dollar against the rupiah at Rp 12.165 and in December 2017 amounted to USD 13.480.

Another factor to be considered to predict the stock gains associated with macroeconomic variables are interest rates. Money or money owed by the company will cause interest to be paid, such interest to be a burden for the company. Under certain conditions, namely when the interest rate banks increased lending, in particular, the burden of the company be increased. This will cause the level of corporate profits will decline. If the company's profit decreased then it will be given a negative response by investors in the form of sales of the company's stock and the stock is transferred to another company with better earnings prospects. This will impact on the company's stock price. In the early period is the SBI interest rate of 7.5\% and in December 2017 amounted to 4, 25\% or decreased. The rate of decline of $4.3 \%$.

PT. Indofood CBP Sukses Makmur Tbk is a big company in Indonesia which acts both as producers and contributors to national products in Indonesia, particularly in consumer products. PT. Indofood CBP Sukses Makmur Tbk has grown to become one of the leading companies for Food \& Beverages products in Indonesia.

The product range PT. Indofood CBP Sukses Makmur Tbk includes leading brands like in Indonesia even in the world such as Indomie, Pop Mie, Indomilk, Chitato, Lays, Indofood soy sauce, seasoning Racik, Promina, Sun, Pepsi, Ichi Ocha and others. During this time the company's vision remains the same, namely be a company that can meet the food needs with top quality products, quality, and safe to consume and become a leader in the food industry.

In the early period of the month of January 2014, a stock price of Rp 11,000 and the end of 2017 amounted to $\mathrm{Rp} 8,900$. If the calculated difference between the purchase price and the final will be obtained rate of profit. Stock profit rate of $1.59 \%$ and at the end of the period amounted to $5.33 \%$.

\section{Literature Review}

\section{Exchange Rate}

According to Musdholifah \& Tony (2007), the exchange rate or the exchange rate is the ratio between the price of a country's currency to another country's currency. Suppose the rupiah against the US dollar shows how much money is required to be exchanged for one US dollar. According to Triyono (2008), exchange rates are an exchange between two different currencies, ie the ratio of the value or price between the two currencies.

Thus, we can conclude the exchange rate is a ratio between the value of the currency of a country with another. Heru (2008) states that the exchange rate reflects a balance of demand and supply on the domestic currency or foreign currency \$ US. The decline of the exchange rate reflects the decrease in public demand for the rupiah because of the declining role of the national economy or because of increased demand for foreign currency \$ US as a means of international payment. Strengthens the rupiah exchange rate to a certain extent means to describe the performance of the money market continued to show improvement. As the impact of rising inflation the domestic exchange rate weakened against foreign currencies.

Heru (2008) states that the value of the rupiah against foreign currencies also had a negative effect on the economy and capital markets. With the decline of the rupiah against foreign currencies will result in increased cost of imported raw materials to be used for the production and also increase interest rates. Although the decline in the exchange rate may also encourage companies to export. 


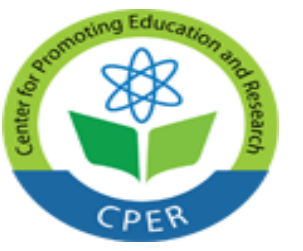

VOL: 1, ISSUE: 2

February/2019

https://ijssppnet.com/

E-ISSN: $x x x x-x x x x$

(C) Center for Promoting Education and Research (CPER) USA

WWW.cpernet.org

\section{Determination of Exchange Rates}

Changes in currency supply and demand something, which in turn causes changes in exchange rates, due to many factors, namely: (Sukirno, 2004: 402).

1. Changes in taste society.

2. Changes in prices of exported and imported goods.,

3. The increase in general prices (inflation).

4. Changes in interest rates and the rate of return on investment.

5. Economic growth.

\section{Currency Exchange System}

According to Triyono (2008) there are five types of exchange-rate system as the principal, namely: a system of floating exchange rates, the rate moored (pegged exchange rate), the rate tied to crawl (crawling pegs), a basket of currencies, the fixed exchange rate.

1. The System of Floating Exchange Rates

The exchange rate is determined by market forces, with or without government interference in stabilization efforts through monetary policy if there is government interference then the

2. System Include Float (managed floating exchange rate).

Exchange rate system anchored A tether country its currency value to something or group of currencies of other countries that are major trading partners of the country concerned, this means that the country's currency moves follow the currencies of countries that are its tether.

3. System Moored Crawl Rate

Where countries make a few changes to its currency on a periodic basis with a view to moving towards a certain value within a certain timeframe. The main advantage of this system is able to measure the state of completion is the exchange rate in over a longer period when compared with the exchange rate system late.

4. Systems Basket Of Currencies

The advantage is that this system offers the stabilization of the country's currency for the currency movements deployed in a basket of currencies. The currency included in the basket is usually determined by the amount of trade finance role in a particular country.

5. Fixed Exchange Rate System

Where the state set and announces a specific exchange rate on its currency and keeps the exchange rate by buying or selling foreign currency in unlimited quantities in the exchange rate. For a country that has a high dependence on the foreign sector as well as disorders such as frequent natural disturbances, setting a fixed exchange rate is a high-risk policy.

\section{Factors Affecting Exchange Rates}

In a fixed exchange rate system, the local currency is set permanently to particular. Sementara currency in a floating exchange rate system, the exchange rate or the rate can change at any time, depending on the supply and demand of foreign currencies relative to the local currency. Any changes in supply and demand of a currency will affect the exchange rate of the currency in question.

In terms of the demand for foreign currencies relative to the domestic currency increases, the value of the domestic currency will decline. Conversely, if the demand for foreign exchange declines, the value of domestic currency increases. However, if the supply of foreign currency increased relative to the local currency, the exchange 


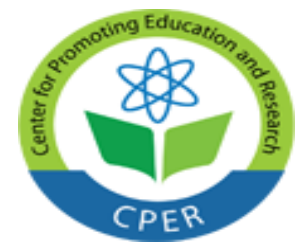

VOL: 1, ISSUE: 2

February/2019

https://ijssppnet.com/

E-ISSN: $x x x x-x x x x$

(C) Center for Promoting Education and Research (CPER) USA

WWW.cpernet.org

value of the domestic currency increases. After that, if the supply decreases, the exchange value of the domestic currency declined.

Judging from the factors that influence it, there are three main factors that affect the demand for foreign exchange, namely:

\section{Factors import payment}

The higher imports of goods and services, the greater the demand for foreign currency so that the exchange rate will tend to weaken. Conversely, if imports declined, the demand for foreign currency decreased so as to encourage the strengthening exchange rate.

6. Factors capital outflows

The greater the capital out, the greater the demand for foreign currency and the sequel will weaken the exchange rate. Capital outflow to cover debt payments Indonesian population (both private and government) to foreigners and placement of Indonesian people abroad.

3. Speculation

More and more foreign exchange speculation activities undertaken by the greater the demand for foreign currency value so as to weaken the exchange rate of the local currency against foreign currencies.

4. Meanwhile, foreign exchange deals are influenced by two main factors, namely:

Factor a percentage of exports

The greater the volume of exports of goods and services receipt, the greater the amount of foreign exchange that is owned by the country and the subsequent exchange rate against foreign currency tends to strengthen or appreciation. On the contrary, if export declines, the amount of foreign exchange owned yuang decreased so that the exchange rate is also likely to depreciate.

5. Factors capital inflows

The larger the capital inflows, the exchange rate will tend to be stronger. Capital inflows can be the acceptance of foreign debt, short-term placement of funds by foreign parties (portfolio investment as) and foreign direct investment.

\section{Interest rate}

Interest is the price of the use of money or bias is also seen as the rent for the use of money for a certain period. Or the price of borrowing money to use its purchasing power and is usually expressed in percent $(\%)$.

The bank rate can be interpreted as a favor granted by the bank based on the principle of Conventional to customers who buy or sell products. Flowers can also be interpreted as a price to be paid to customers (who have deposits) to be paid by the customer to the bank (Kashmir, 2002: 121).

In everyday banking activities, there are two kinds of flowers are given to customers, namely:

1. Deposit interest is interest that is given as stimulation or as a reward for customers who keep money in the bank. Deposit interest is the price that must be paid by a bank to its customers. Example: services.

2. The loan interest is interest that is given to the borrower or the price paid by the customer to the bank loan. Example: lending.

Both kinds of this flower is a major component of cost and revenue for the bank. The savings rate is the cost of money should be spent to customers while the interest on the loan is income received by customers. Both deposit 


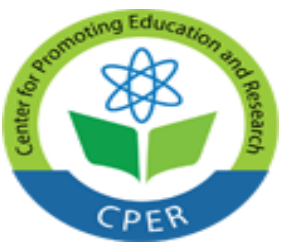

VOL: 1, ISSUE: 2

February/2019

https://ijssppnet.com/

E-ISSN: $x x x x-x x x x$

\section{(C) Center for Promoting Education and Research (CPER) USA}

WWW.cpernet.org

and lending interest each influence each other. For example, if high borrowing costs, it will automatically affect lending rates also go up and vice versa.

\section{Factors That Affect Interest Rates}

In order for bank profits to the maximum, then the bank's management must be proficient in determining the size of the interest rate component. It is caused when the wrong in determining the size of the interest rate component would be detrimental to the bank itself. Factors affecting the determination of interest rates, namely:

\section{Funding Needs}

Factors funding requirements specific to savings that is, how much money needs to be desired. If banks are underfunded, while loan applications increased, it is done by the bank in order and quickly met is to increase the interest rates on deposits. But the increase in deposit rates will also increase interest rates on loans. Conversely, if the existing funds in bank deposit many, while for loans less then bung savings will go down.

2. Target Profit Desired

This factor is devoted to the interest on the loan. This is due to the profit target is one component in determining the size of the loan interest rate. If desired profit big then the loan interest is also large and vice versa. However, to deal with competitors profit targets can be lowered to a minimum.

3. Quality Assurance

Quality assurance is also destined to flower. The more liquid collateral (liquid) is given, the lower the interest rate charged and vice versa.

4. Government Policy

In determining deposit rates and lending rates, banks should not be over limits set by the government. That is no maximum limit and no limit allowed minimal for interest rates. The aim is that the bank can run private compete healthily.

5. Term

Good for deposit and lending rates, a period of time factor is crucial. The longer the loan term, the higher the interest. This is due to the magnitude of the possible risk of future jams. And vice versa if the short-term loans, the interest rates are relatively low. But the savings rate applicable to the contrary, the longer the period the lower the savings rate and vice versa.

6. Corporate Reputation

The company's reputation also determines the interest rates, especially for lending. The reliability of an enterprise that will largely determine loan interest rate to be charged later on because normally companies are a bonafide possible risk of future bad loans are relatively small and vice versa companies that lack a bona fide risk factor for bad debts is quite large.

7. Competitive Products

Competitive products determine the size of the loan. Competitive products are financed intention is highly marketable. For products that are competitive, Credit interest is relatively low when compared to a less competitive product. This is due to the competitive product turnover rate is high so that the payment expected product smoothly.

8. Good Relations

Usually lending credence to the factor associated with a person or institution. In practice, banks classify clients between customer's main (primary) and regular customers (secondary). 


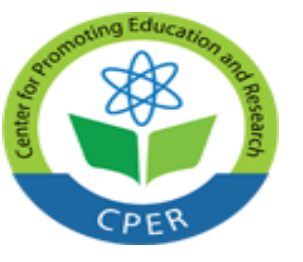

VOL: 1, ISSUE: 2

February/2019

https://ijssppnet.com/

E-ISSN: $x x x x-x x x x$

\section{(C) Center for Promoting Education and Research (CPER) USA}

WWW.cpernet.org

\section{Competition}

In unstable conditions and bank short of funds while the level of competition for deposits is quite tight, then the bank must compete with other banks.

The interest rate is a value which the interest is paid by the borrower (debitor) to use the money they borrow from a lender (creditor). Interest rates are normally expressed as a percentage of the principal for a period of one year, sometimes they are declared for a different time period such as one month or one day.

Different interest rates are in parallel to the same period of time or can be likened, depending on the probability of default of the borrower, the rest of the time period, the payment currency, and more determinant of a loan or credit. For example, a company borrows money from banks to buy new assets for its business, and in return, the lender receives the rights to the new asset as collateral and the interest on the interest rate has been determined. The replies received by the bank as a favor to delay the use of these funds and prefer to lend to the borrower.

\section{Stock Prices}

The stock is the present value of cash flows to be received by shareholders in the future. According to Anoraga (2001: 100) the stock price is the money spent to obtain proof of ownership or ownership of a company. Stock prices can also be interpreted as a price that is formed from the interaction of buyers and sellers of shares against the background by their expectations for corporate profits, for that investor need information relating to the formation of these shares in the decision to sell or buy shares.

The share price is the price formed on the stock exchange. In general, the share price is obtained to calculate the value of its shares. The further these differences, it reflects too little information flowing to the stock exchange. The share price tends to be influenced by psychological pressure buyers or sellers. To prevent this, the company should at any time provide sufficient information to the stock exchange, as long as the information is an effect on the market price of its shares. Efforts to incorporate how to calculate the actual stock price has done any analysis with the aim to obtain a satisfactory profit level. However, it is difficult for investors to continue to outperform the market and gain when the rate of profit above the normal.

\section{Factors That Affect Stock Prices}

According to Arifin (2004) factors that affect stock prices are as follows:

\section{The fundamental condition of issuers}

Fundamental factors are factors directly related to the performance of the issuer itself. The better the performance of the issuer, the greater the impact on stock prices and vice versa. To ascertain whether the condition of the issuer in a good position or bad we could perform ratio analysis approach.

2. The law of supply and demand

The law of supply and demand factors came second after a fundamental factor because so investors know the company's fundamentals surely they would do better sale or purchase transaction. These transactions will affect the stock price fluctuation.

3. The interest rate

With the changes in interest rates, the return on the results of various investment vehicles will be amended. High interest will have an impact on the allocation of investment funds to investors. Investor products such as deposits or savings bank clearly smaller, when compared to the investment risks in shares, as investors will sell stocks and funds, will be placed in the bank. Simultaneous sale of shares will impact on the stock price significantly.

4. Foreign exchange 


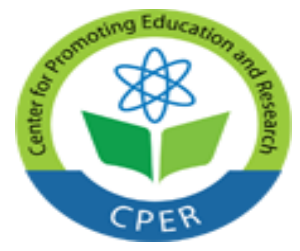

VOL: 1, ISSUE: 2

February/2019

https://ijssppnet.com/

E-ISSN: $x x x x-x x x x$

\section{(C) Center for Promoting Education and Research (CPER) USA}

WWW.cpernet.org

American currency (dollar) is the strongest currency among other currencies. If the dollar rises, foreign investors will sell their shares and placed in banks in the form of dollars, causing the stock price will go down.

5. Foreign funds on the exchange

Viewing the number of foreign investment funds is important because as the number of funds invested, it indicates that the investment conditions in Indonesia have been conducive to significant economic growth is no longer negative, which of course will stimulate the issuer's ability to generate profit. Conversely, if the foreign investment is reduced, there is the consideration that they are skeptical of the country, both on socio-political as well as security. So the size of the investment of foreign funds in the stock will have an effect on the increase or decrease in the stock price.

6. Share price index

The increase in the stock price index all the time, of course, brings in investment conditions and the country's economy is in good condition. Conversely, if the down means being a poor investment climate. Such conditions will affect the rise or fall of stock prices in the stock market.

7. News and rumors

The definition of news and rumors are all the news circulating in the community concerning some good things in the economic, social, political, security, to news about a cabinet reshuffle. With the news, investors can predict how conducive the country's security so that investment activity can be carried out. It will have an impact on stock price movement in the stock.

Based on the statements above it can be concluded that the factors that determine changes in stock prices are very diverse. But the main thing is the strength of the market itself, namely supply and demand for shares itself. In accordance with the laws of economics, the higher the demand for these shares then the stock price will rise.

\section{Research Methods}

\section{Research Design}

This study uses an explanatory analysis approach. This means that each of the variables presented in the hypothesis will be observed by testing the causal relationship of independent variables on the dependent variable.

That phenomenon can be designed through the following mathematical functions:

\section{Model 1 (one)}

Simultaneously influence between X1 (the exchange rate) and X2 (SBI rate) to variable Y (profit share) can be formulated with:

$Y=\mathrm{F}(\mathrm{X} 1, \mathrm{X} 2)$

Assuming probability predictor variables are the same $(P \# 0,000) /<0,05$

\section{Model 2 (two)}

The influence of the independent variables $\mathrm{X} 1$ (the exchange rate) to $\mathrm{Y}$ (profit share) can be formulated with: $Y=f\left(X_{1}\right)$

Assuming probability is not the same predictor variables $(P \# 0,000) /<0,05$,

\section{Model 3 (three)}

Partial effect between X2 (SBI) to Y (profit share) can be formulated with:

$Y=f\left(X_{2}\right)$

Assuming probability is not the same predictor variables. 


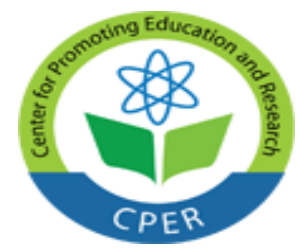

VOL: 1, ISSUE: 2

February/2019

https://ijssppnet.com/

E-ISSN: $x x x x-x x x x$

(C) Center for Promoting Education and Research (CPER) USA

WwW.cpernet.org

\section{Results and Discussion}

\section{Developments Exchange Rate}

The rupiah is a comparison between the value of the currency of a country with another. Heru (2008) states that the exchange rate reflects a balance of demand and supply on the domestic currency or foreign currency $\$$ US. The decline of the exchange rate reflects the decrease in public demand for the rupiah because of the declining role of the national economy or because of increased demand for foreign currency \$ US as a means of international payment. Semkin strengthens the rupiah exchange rate to a certain extent means to describe the performance of the money market continued to show improvement. As the impact of rising inflation the domestic exchange rate weakened against foreign currencies. This resulted in a decreased performance of a company and investment in the capital market be reduced.

The exchange rate of the dollar against the rupiah at Rp 12.165 in January 2014 and in December 2017 the value increased by USD 13.480. The average increase is $0.27 \%$. In the form of graphs that can be described as follows.

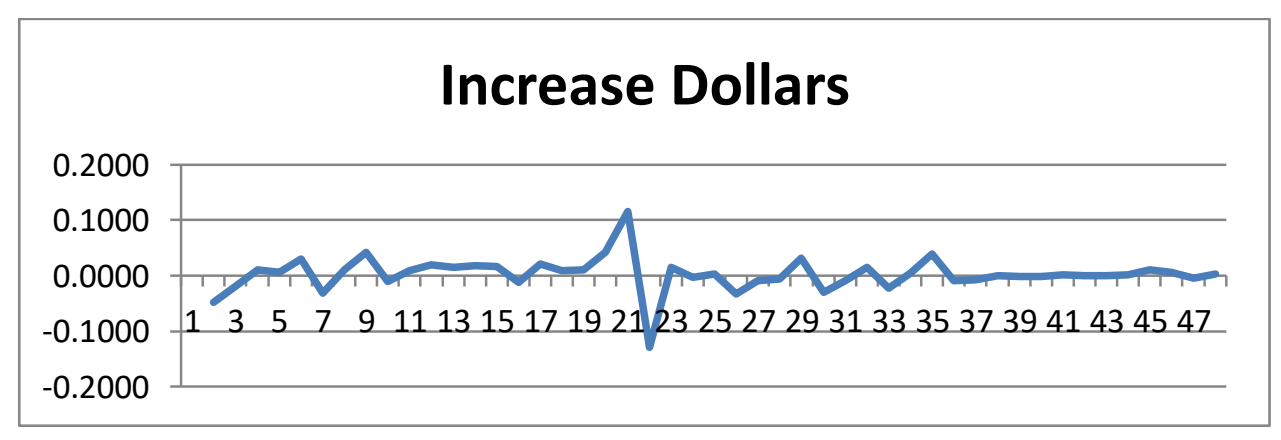

Figure 1. Increase in the dollar against the rupiah in 2014-2017

Based on the picture above note pad dollar rise in February 2014 amounted to $-4.484 \%$ and at the end of the period amounted to $0.25 \%$.

\section{SBI Interest Rate Movement}

The bank rate can be interpreted as a favor granted by the bank based on the principle of Conventional to customers who buy or sell products. Flowers can also be interpreted as a price to be paid to customers (who have deposits) to be paid by the customer to the bank, customers who obtained a loan (Kashmir, 2002: 121). Developments SBI hikes interest rate cuts may be seen in the following figure.

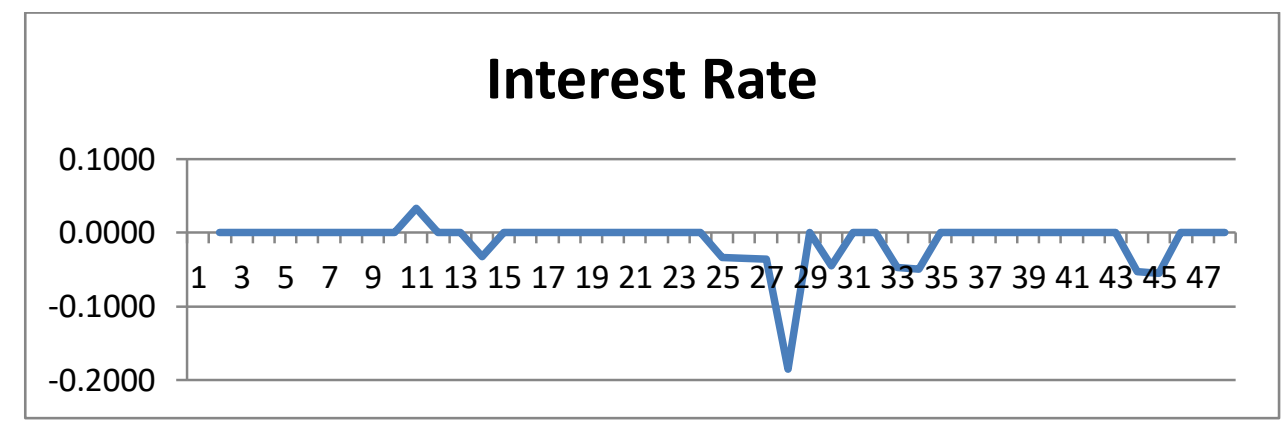

Figure 2. Development of SBI interest rate 


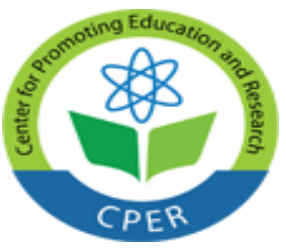

VOL: 1, ISSUE: 2

February/2019

https://ijssppnet.com/

E-ISSN: $x x x x-x x x x$

(C) Center for Promoting Education and Research (CPER) USA

WWW.cpernet.org

The amount of SBI interest rate of 7.5\% in January 2014 and in December 2017 the amount of SBI interest rate of $4.25 \%$. In this period there is a decrease in the SBI interest rate of $1.15 \%$. The image also shows the development of interest rates relatively constant figure shows a horizontal line on some of the observation period.

\section{The Company's Profit Development}

The researchers looked at IPO in the capital market (IPO) as a matter of interest, due to the phenomenon of underpricing. Husnan and Hanafi (2012) observed the behavior of stock prices in the primary market, underpricing phenomenon that has occurred during the 1990s.

Investors and security analysis that has information about the condition of the actual price of securities companies connect with intrinsic value. If the stock price is overvalued, then at the time of the trade on the exchange, investors will sell shares they own or avoiding the purchase of shares, otherwise if the price of the stock rated undervalued, then at the time of the trade on the exchange, investors will be compelled to make a purchase or hold when the shares were owned. Their market correction resulted in overvalued stock prices tend to go down and undervalued share price will tend to rise when traded in the secondary market. Both will be moved closer to the supposed value of a stock or so-called intrinsic value.

In January 2014 the company's stock price is Rp 11,000. In December 2017 the share price decreased by Rp 8,900 . During that period there was an increase of $0.17 \%$. The share price in the form of graphs can be seen in the following curve.

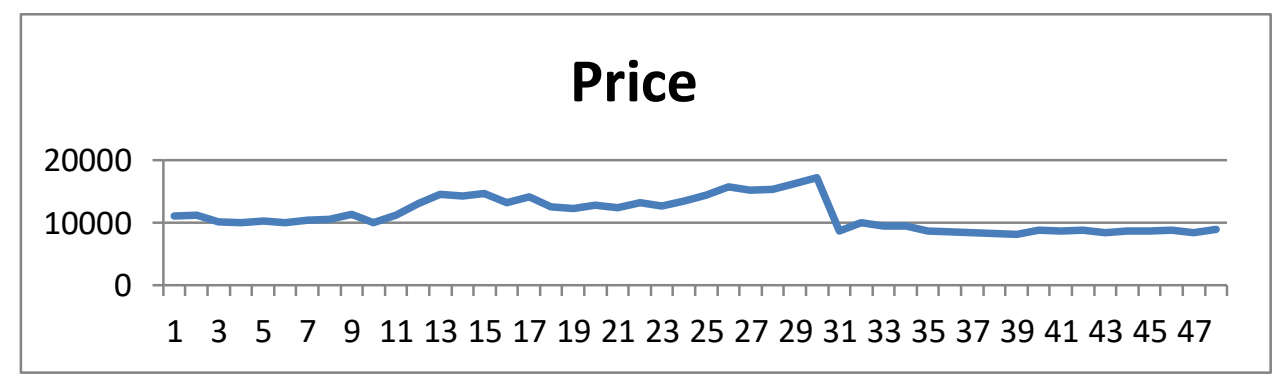

Figure 3. Development of share price

In December 2017 the share price decreased by Rp 8,900. During that period there was an increase of $0.17 \%$. The share price in the form of the graph is experiencing a decrease and increase in the period.

The price can be prepared from stock gains obtained a level of reduction in stock prices of a certain period with the previous period is then divided by the share price of the previous period. Results of the calculations can be presented in the following figure.

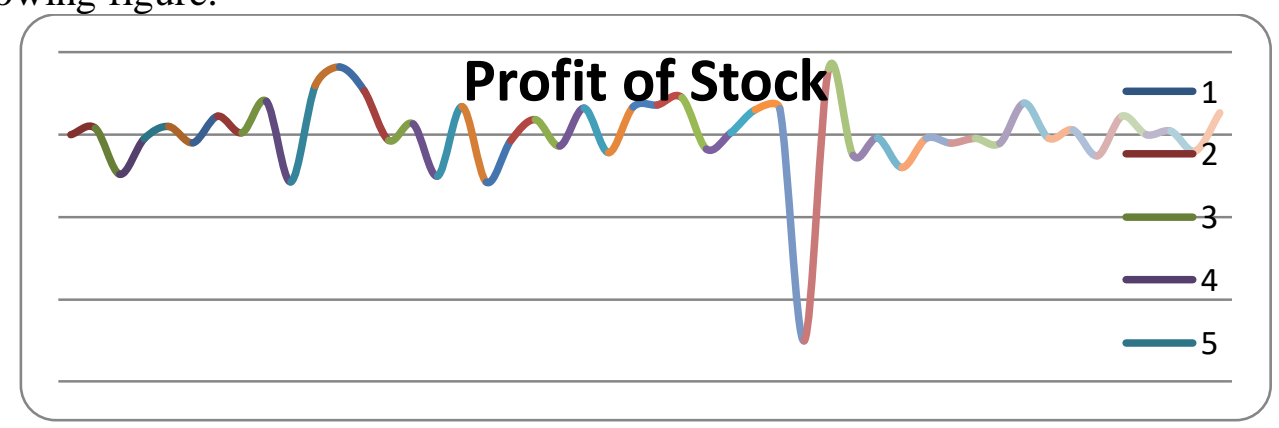

Figure 4. Development of the stock profits 
VOL: 1, ISSUE: 2

February/2019

https://ijssppnet.com/

E-ISSN: $x x x x-x x x x$

(C) Center for Promoting Education and Research (CPER) USA

WWW.cpernet.org

Based on the curve above image can be analyzed that the early period of the company's stock gain was $1.59 \%$ and at the end of the study period the stock profit rate increased to $5.33 \%$. The average increase in profit shares was $0.17 \%$.

\section{Discussion}

\section{Effect of Exchange Rate and Interest Rate on Stocks Gain}

The analytical model can be based on calculations using SPSS program as follows.

Table 1. Results of the analysis of the effect of X1 and X2 on Y

Coefficients

\begin{tabular}{|c|c|c|c|c|c|c|}
\hline & \multirow[b]{2}{*}{ Model } & \multicolumn{2}{|c|}{$\begin{array}{l}\text { Unstandardized } \\
\text { coefficients }\end{array}$} & \multirow{2}{*}{$\begin{array}{c}\begin{array}{c}\text { Standardized } \\
\text { coefficients }\end{array} \\
\text { beta }\end{array}$} & \multirow[b]{2}{*}{ t } & \multirow[b]{2}{*}{ Sig. } \\
\hline & & B & Std. Error & & & \\
\hline \multirow[t]{3}{*}{1} & (Constant) & $-12,510.192$ & 5684.852 & & -2.201 & 033 \\
\hline & EXCHANGE & 1,207 & , 386 & , 378 & 3.129 &, 003 \\
\hline & FLOWER & $128,945.009$ & 22582.828 & 690 & 5.710 & 000 \\
\hline
\end{tabular}

a. Dependent Variable: BENEFITS

Based on the above table can be created multiple regression models as follows

$\mathrm{Y}=-12,510.192+1,207 \mathrm{X} 1+128945,009 \mathrm{X} 2$

$\mathrm{F}$ count can be seen in the following table.

Table 2. Values first $\mathbf{F}$ arithmetic equation

ANOVAa

\begin{tabular}{|ll|l|r|r|r|l|}
\hline \multicolumn{1}{|c|}{ Model } & Sum of Squares & \multicolumn{1}{c|}{ df } & mean Square & F & Sig. \\
\hline 1 & Regression & $132,771,145.346$ & 2 & $66,385,572.673$ & 16.943 &, $000 \mathrm{~b}$ \\
& residual & $176,317,135.904$ & 45 & $3,918,158.576$ & & \\
& Total & $309,088,281.250$ & 47 & & & \\
\hline
\end{tabular}

a. Dependent Variable: BENEFITS

b. Predictors: (Constant), INTEREST, EXCHANGE

Berdasarkana in the table above is known that have calculated F value of 16.943 with a significance of 0.00 . The significance value of less than 0.05 is the value of alpha. Variable exchange rates and interest rates SBI affect the company's stock gains simultaneously.

The magnitude of the effect of variable exchange rates and interest rates SBI affect the company's stock price can be seen from the following values of $\mathrm{r}$ squared.

Table 3. Values first equation r squared Model Summaryb

\begin{tabular}{|l|c|r|r|r|r|}
\hline Model & $\mathrm{R}$ & R Square & $\begin{array}{c}\text { Adjusted R } \\
\text { Square }\end{array}$ & $\begin{array}{c}\text { Std. Error of the } \\
\text { Estimate }\end{array}$ & Durbin-Watson \\
\hline 1 &, $655 \mathrm{a}$ &, 430 &, 404 & 1979.43390 &, 684 \\
\hline
\end{tabular}

a. Predictors: (Constant), INTEREST, EXCHANGE

b. Dependent Variable: BENEFITS 


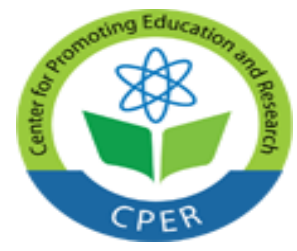

VOL: 1, ISSUE: 2

February/2019

https://ijssppnet.com/

E-ISSN: $x x x x-x x x x$

(C) Center for Promoting Education and Research (CPER) USA

WWW.cpernet.org

Based on the above table are known $\mathrm{r}$ squared value of $43.0 \%$. Its means variable exchange rate and the SBI interest rate effect on profit shares of the company amounted to $43.0 \%$ while the rest influenced by other variables not included in the model equations.

\section{Effect of exchange rate on the stock gain}

Based on the partial analysis above, it can be described as follows.

Table 4. The regression equation to three

Coefficients

\begin{tabular}{|c|c|c|c|c|c|c|}
\hline & \multirow[b]{2}{*}{ Model } & \multicolumn{2}{|c|}{$\begin{array}{l}\text { Unstandardized } \\
\text { coefficients }\end{array}$} & \multirow{2}{*}{$\begin{array}{c}\text { Standardized } \\
\text { coefficients }\end{array}$} & \multirow[b]{2}{*}{$\mathrm{t}$} & \multirow[b]{2}{*}{ Sig. } \\
\hline & & $\mathrm{B}$ & Std. Error & & & \\
\hline \multirow[t]{2}{*}{1} & (Constant) & 5989.729 & 6067.178 & &, 987 &, 329 \\
\hline & EXCHANGE &, 407 & 467 & 128 &, 872 & 388 \\
\hline
\end{tabular}

a. Dependent Variable: BENEFITS

Based on the above table it is known that $\mathrm{Y}=5989.729+0,407 \mathrm{X} 1$

$\mathrm{T}$ value of 0.872 with a significance value of 0.388 . The significance values greater than 0.05 so it can be said that the exchange rate does not affect the profit shares of the company being investigated. The magnitude of the effect of the variable exchange rate to stock gains can be seen in the following table.

Table 5. Values r squared second equation

Model Summary

\begin{tabular}{|l|r|r|r|r|}
\hline Model & $\mathrm{R}$ & R Square & Adjusted R Square & $\begin{array}{c}\text { Std. Error of the } \\
\text { Estimate }\end{array}$ \\
\hline 1 &, $128 \mathrm{~A}$ & .016 &,- 005 & 2570.98928 \\
\hline
\end{tabular}

a. Predictors: (Constant), RATE

Based on the above r-table squared value of $1.6 \%$. This value shows the effect of the exchange rate variable to share gains of $1.6 \%$ and the rest is influenced by other variables that are not included in the analysis tables.

\section{Effect of SBI on Stocks Gain}

Based on the partial analysis above, it can be described as follows.

Table 6. The regression equation to three Coefficients

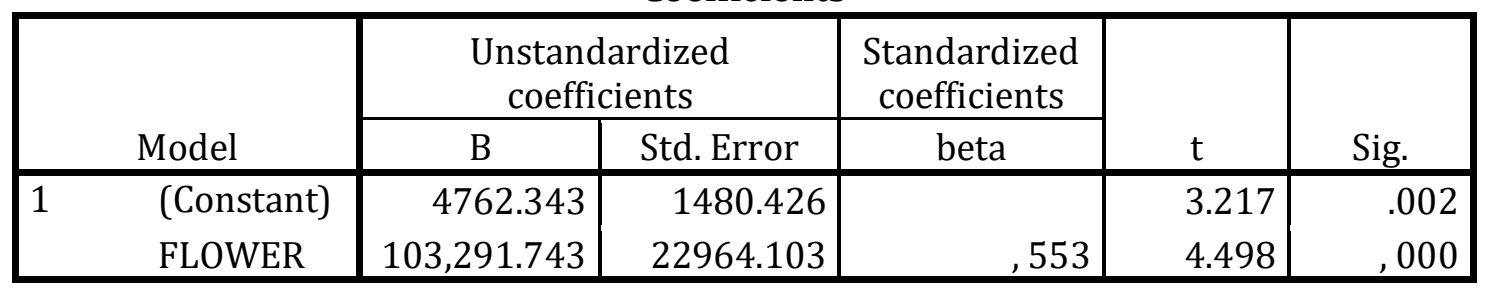

a. Dependent Variable: BENEFITS

Based on the above table it is known that $\mathrm{Y}=4762.343+103291,743 \mathrm{X} 2$

$\mathrm{T}$ value of 4.498 with a significance value of 0.00 . The significance value less than 0.05 so it can be said that the SBI variables affect the profit shares of the company being investigated. SBI variable amount of influence on stock gains can be seen in the following table. 


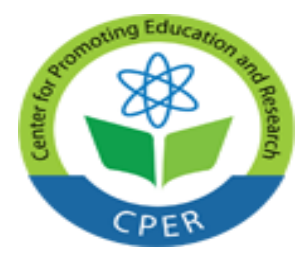

VOL: 1, ISSUE: 2

February/2019

https://ijssppnet.com/

E-ISSN: $x x x x-x x x x$

(C) Center for Promoting Education and Research (CPER) USA

WWW.cpernet.org

Table 7. The third equation $r$ squared

Model Summary

\begin{tabular}{|l|r|r|r|r|}
\hline Model & $\mathrm{R}$ & \multicolumn{1}{c|}{ R Square } & Adjusted R Square & $\begin{array}{c}\text { Std. Error of the } \\
\text { Estimate }\end{array}$ \\
\hline 1 &, $553 \mathrm{a}$ &, 305 &, 290 & 2160.27151 \\
\hline
\end{tabular}

a. Predictors: (Constant), INTEREST

Based on the above r-table squared value of $30.5 \%$. This value indicates the SBI variables influence on stock gains of $30.5 \%$ and the rest is influenced by other variables that are not included in the analysis tables.

\section{Conclusions and Suggestions}

\section{Conclusion}

Variable exchange rates and interest rates SBI affect the company's stock gains simultaneously. Calculated F value of 16.943 with a significance of 0.00 . The significance value of less than 0.05 is the value of alpha. $R$ squared value of $43.0 \%$. Its means variable exchange rate and the SBI interest rate effect on profit shares of the company amounted to $43.0 \%$ while the rest influenced by other variables not included in the model equations.

The exchange rate has no effect on the company's stock gains were studied. T value of 0.872 with a significance value of 0.388 . The significance values greater than 0.05 . R squared value of $1.6 \%$. This value shows the effect of the exchange rate variable to share gains of $1.6 \%$ and the rest is influenced by other variables that are not included in the analysis tables.

Variable SBI affects the profit shares of the company being investigated. T value of 4.498 with a significance value of 0.00 . The significance value less than 0.05 . R squared value of $30.5 \%$. This value indicates the SBI variables influence on stock gains of $30.5 \%$ and the rest is influenced by other variables that are not included in the analysis tables.

\section{Suggestion}

Investors need to consider the value of the dollar against the rupiah exchange rate and interest rate of Bank Indonesia Certificate (SBI) to invest in shares. Indofood CBP Sukses Makmur Tbk. This is due to the variables studied influence stock gains together or simultaneously.

Variable interests rates need to be considered specifically for the variable partial effect on stock gains were studied. Value of data can be viewed on the Bank Indonesia website or other sites related to the publication of data on the companies concerned.

Future studies need to consider other variables that predicted influence the company's stock gains investigated. These variables can be considered derived from the company's fundamentals and macroeconomic fundamental factors. 


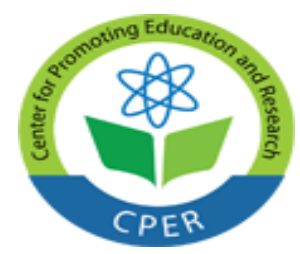

VOL: 1, ISSUE: 2

February/2019

https://ijssppnet.com/

E-ISSN: $x x x x-x x x x$

(C) Center for Promoting Education and Research (CPER) USA

WwW.cpernet.org

\section{References}

AgusSartono. (2008). ManajeenKeuanganTeoridanAplikasiedisiempat Yogyakarta: BPFE.

Ali Arifin.(2004).MembacaSaham.PenerbitAndi: Yogyakarta

Anoraga, PandjidanPijiPakarti.(2001). PengantarPasar Modal.Jakarta : PT RinekaCipta.

Hanafi, Mamduh M. dan Abdul Halim, (2014), AnalisisLaporanKeuangan., Edisitujuh., UPP AMP YKPN, Yogyakarta.

Husnan, SuaddanEnnyPudjiastuti, (2012), Dasar-DasarManajemenKeuangan., EdisiKeenam., CetakanPertama., Yogyakarta: UPP STIM YPKN

Kasmir.(2002). Dasar-dasarPerbankanEdisiRevisi. Jakarta: PT. Raya GrafindoPersada.

Musdholifah\& Tony. (2007). Http://Imamsetiyantoro.Wordpress.Com/2012/02

Nugroho, Heru. (2008). AnalisispengaruhInflasi, SukuBungadanJumlahuangberedarterhadap return SahamterhadapIndeks LQ45 pada BEI 2002- 2007).Tesis Magister ManajemenUniversitasDiponegoro. Semarang. (tidakdipublikasikan).

Sukirno, Sadono. (2004). PengantarTeoriMakroekonomi. Jakarta: PT Raja GrafindoPersada

Triyono (2008).“AnalisisPerubahanKurs Rupiah Terhadap Dollar Amerika.EkonomiPembangunanVol.9, No. 2, Desember, hal. 156 - 167. 